\title{
BUSINESS BENEFITS OF LICENSED SHARED ACCESS (LSA) FOR KEY STAKEHOLDERS
}

Marja MatinmikKo

VTT Technical Research Centre of Finland, Finland

HANNA OKKONEN

Oulu Business School, Finland

SEPPO YRJÖLÄ

Nokia, Finland

Petri Ahokangas

Oulu Business School, Finland

Mita Mustonen and Marko Palola

VTT Technical Research Centre of Finland, Finland

VÂNIA GonÇALVES

Vrije Universiteit Brussel, Belgium

ANRI KIVIMÄKI

Oulu Business School, Finland

Esko LuTTINEN

University of Oulu, Finland

JUKKA KEMPPAINEN

EXFO, Finland

Opportunistic Spectrum Sharing and White Space Access: The Practical Reality, First Edition. Edited by Oliver Holland, Hanna Bogucka, and Arturas Medeisis.

(C) 2015 John Wiley \& Sons, Inc. Published 2015 by John Wiley \& Sons, Inc. 


\subsection{INTRODUCTION}

Mobile traffic predictions summarized in [1] are indicating growing data rate demand for mobile communication networks. LTE-Advanced networks are supporting new technical features to deliver higher data rates with higher spectral efficiencies, such as carrier aggregation, load balancing, traffic steering, active antenna, multi-antenna evolution, heterogeneous networks, relays, coordinated multipoint, and self-organizing networks [2]. However, radio technology improvements alone will not be sufficient to meet the growing demand. Additionally, the growing traffic demand calls for additional spectrum for future cellular networks. Wider carrier bandwidths are particularly interesting to complement the currently available cellular bands to fully realize the benefits of the new technology.

Today, the spectrum options for cellular networks to offer high service levels are exclusive licensed bands, while license-exempt bands are used for traffic off-loading. In the future, new ways of spectrum access based on the principle of sharing will be vital, see [3]. Access to shared spectrum bands will become an appealing complementary alternative for mobile network operators (MNOs) to meet the growing demand in a timely manner as clearing bands from current uses and reallocating them to mobile is time-consuming and costly.

The focus on spectrum sharing has now moved from license-exempt secondary sharing toward a new Licensed Shared Access (LSA) approach, which is being developed in regulatory, business, and technical domains in Europe. The Radio Spectrum Policy Group (RSPG) of the European Commission (EC) has defined the LSA concept in November 2013 in [4] as "A regulatory approach aiming to facilitate the introduction of radiocommunication systems operated by a limited number of licensees under an individual licensing regime in a frequency band already assigned or expected to be assigned to one or more incumbent users. Under the LSA approach, the additional users are authorised to use the spectrum (or part of the spectrum) in accordance with sharing rules included in their rights of use of spectrum, thereby allowing all the authorized users, including incumbents, to provide a certain Quality of Service (QoS)." The main idea in LSA is to allow additional licensed users to bands that already encompass incumbent spectrum users while guaranteeing operational certainty for both the entrants and the incumbents.

The LSA concept is broad and could be applied to different wireless systems and the main ongoing effort is to apply it to mobile broadband such that an MNO would be allowed to access bands identified for International Mobile Telecommunication (IMT) systems but currently encompassing other type of incumbent use by sharing with the incumbent spectrum users. The focus in this chapter is to apply the new LSA concept for MNOs to broaden their spectrum options for future cellular networks to meet the growing traffic demand. In particular, we review the high-level concept and regulatory status for LSA and analyze the business potential of sharing based on the LSA concept for future cellular networks. To make this happen, the purpose of this research is to identify the key stakeholders involved in the LSA concept and understand their business benefits. More specifically, the objectives of this chapter are as follows: 
1. Describe the high-level approach for the LSA concept;

2. Describe the LSA business opportunities in terms of needs, benefits, and constraints of spectrum sharing using the LSA for the key stakeholders;

3. Assess the business potential of LSA for future cellular networks by identifying the roles of the key stakeholders in the LSA concept and their relationships.

The rest of this chapter is organized as follows. We start by identifying the underlying spectrum sharing framework and introducing the LSA concept. Next, the key stakeholders in LSA and their business relations are discussed. Then, the key stakeholders' needs, benefits, and constraints are identified. Finally, conclusions are drawn toward a unified view for the adoption of the LSA concept.

\subsection{LSA CONCEPT}

Future cellular networks could be deployed on different types of spectrum bands, namely, exclusively licensed IMT bands, license-exempt bands, and shared bands. It is desirable for MNOs to maintain control over the spectrum over a long time to allow return on network investments. Thus, exclusively licensed globally harmonized spectrum bands with long license durations continue to be preferable from the MNOs' point of view. The use of license-exempt bands by MNOs is today limited due to the unguaranteed interference environment and short-range connectivity including mainly WiFi off-loading. In the future, LTE technology evolution could be developed for new license-exempt bands to complement the current spectrum options.

Access to shared bands under license-exempt regimes, such as the TV white spaces approach, has not been desirable for MNOs due to the uncontrolled interference environment between secondary users and lack of long-term spectrum availability guarantees. However, access to shared bands under licensing agreements could guarantee desirable conditions resembling exclusive licensing. The new LSA approach has recently attracted great interest as a means for licensed sharing for MNOs, see $[5,6]$ about recent standardization and regulatory developments in Europe. In fact, the first live trial of the LSA concept was shown in Finland in April 2013 [7].

In the past, access to shared bands was not considered important for MNOs but is likely to become more important in future cellular networks to meet the growing traffic demand. In order to implement sharing, the spectrum sharing framework that consists of technical, regulatory, and business domains needs to be defined, see [8]. In general, the key stakeholders in the LSA framework include spectrum regulator, licensee, and incumbent spectrum user [4-6]. A major benefit envisioned with LSA is that the number of LSA licensees is limited and that these LSA licensees are known to each other. In the special case of LSA applied to mobile broadband, the spectrum regulator is the national regulatory authority (NRA), the licensee is an $\mathrm{MNO}$, and the incumbent spectrum licensee is a non-MNO. There can be different types of MNOs as licensees, such as challenger and dominating MNOs that have very distinct strategies in spectrum sharing as described in [8] and therefore their businesses need to be 


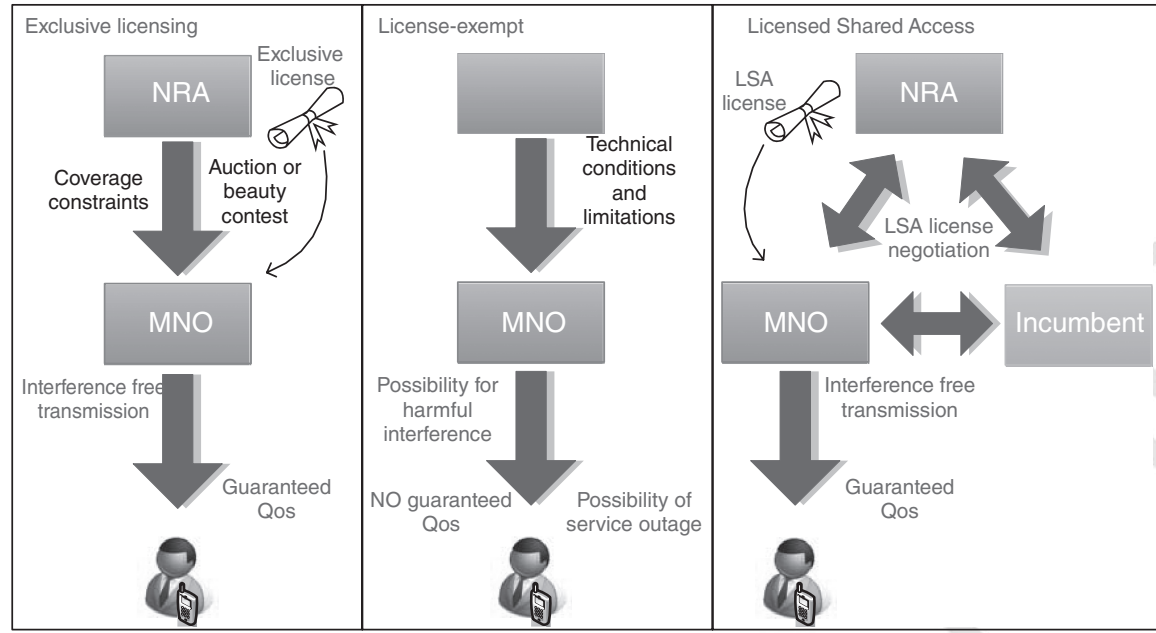

Figure 18.1 Spectrum options and involved stakeholders.

analyzed separately. In addition, the incumbent can be a governmental or commercial, i.e., profit or nonprofit entity.

The currently envisaged technical approach for cellular networks with LSA is based on two new components, namely, LSA Repository and LSA Controller as summarized in [5, 6]. The LSA Repository is the means for presenting the LSA spectrum band availability information that is obtained from the incumbent spectrum users. The LSA Controller is needed by the MNO for using the LSA spectrum information to manage its networks according to the LSA band availability. The LSA is not foreseen to require changes to the user equipment except that the band needs to be supported by the device. Figure 18.1 illustrates the spectrum options and involved key stakeholders. In traditional exclusive licensing, the NRA assigns a license to the MNO while in license-exempt bands it suffices to follow the rules set by the NRA. In the LSA concept, the incumbent also plays a role in addition to the NRA by allowing additional users to access the same band it is using.

In consideration of concrete examples of frequency bands for the application of the LSA concept, the $2.3-2.4 \mathrm{GHz}$ band has been selected for more detailed study, see [5]. It is already an IMT band identified by the ITU-R and is in use in some countries, e.g., in Asia, and is also specified as band 40 in 3GPP. It is widely supported in terminals including multimode multiband smart phones. According to a study [9], the net present values of the benefits from deploying LSA in the 2.3-2.4 GHz band over the period 2015-2030 in Europe span a range, from EUR 6.5 billion to EUR 20 billion, with a medium value of around EUR 12 billion. To make the concept successful, the resulting LSA sharing framework should benefit all involved stakeholders. Therefore, in the following, we assess their business relations in the LSA concept to derive benefits. 


\subsection{BUSINESS RELATIONSHIPS IN LSA}

The concept of networked or ecosystemic business model has emerged to describe and explain how companies create and capture value in the realm of business opportunities and competitive advantages as perceived by the stakeholders [10]. In emerging dynamic and complex environments, business models help to answer the questions what companies are offering to their customers in terms of products/services and value proposition, how and where they are planning to do that in practice, and why do they think they can do it profitably [11]. The business model concept can help to anticipate how stakeholders could benefit from LSA in the future. The key is to build alternative business models by looking at how companies explore and exploit [12] their perceived business opportunities and competitive advantages and calibrate them to the business context [13]. Instead of building alternative business models, this chapter looks at the antecedents of the business models by first identifying the key stakeholders of the LSA concept. LSA brings along a networked or ecosystemic business model and its future as a business case depends on its stakeholders' ability to create profits.

As value creation and capture are crucial elements of business models, in networked or ecosystemic businesses, we must pay attention to value co-creation, co-capture, and co-opetition (parallel cooperation and competition [14]) between the four key stakeholder roles in LSA: that of the NRA, incumbent spectrum user, as well as dominating and challenger MNOs. The value co-creation, co-capture, and co-opetition can be analyzed by discussing in a parallel manner the possible needs, benefits, and constraints of the LSA stakeholders.

\subsubsection{Relations Between Key Stakeholders}

The relations between the key stakeholders in the LSA concept are depicted in Figure 18.2. The incumbent spectrum user offers parts of its unused spectrum bands to be shared with others and gains approval from the NRA. The NRA gives a license to the MNO (dominant or challenger MNO) to access the LSA band. The dominant MNO is assumed to have a strong market position and sufficient amount of spectrum while a challenger MNO has smaller market share and less licensed spectrum, if any, as described in [8]. Dominant MNO could acquire additional LSA bands to respond to growing traffic demand while challenger MNO could diversify into new high-growth businesses with new LSA bands.

Even though the spectrum is shared through the NRA, the business relationships could be managed directly between the incumbent and the MNOs depending on the national situation (e.g., legislation). The NRA is the enabler of all sharing business and vital for each stakeholder as it supervises that meaningful spectrum sharing rules and conditions are first created and later followed. For the incumbent, the relationship with the NRA is necessary but also helpful, since the spectrum sharing is supervised by a third party and the LSA does not reside directly between the incumbent and the MNO. The triangulation between incumbent, NRA, and MNOs also guarantees negotiated QoS and handling breach of contracts. 


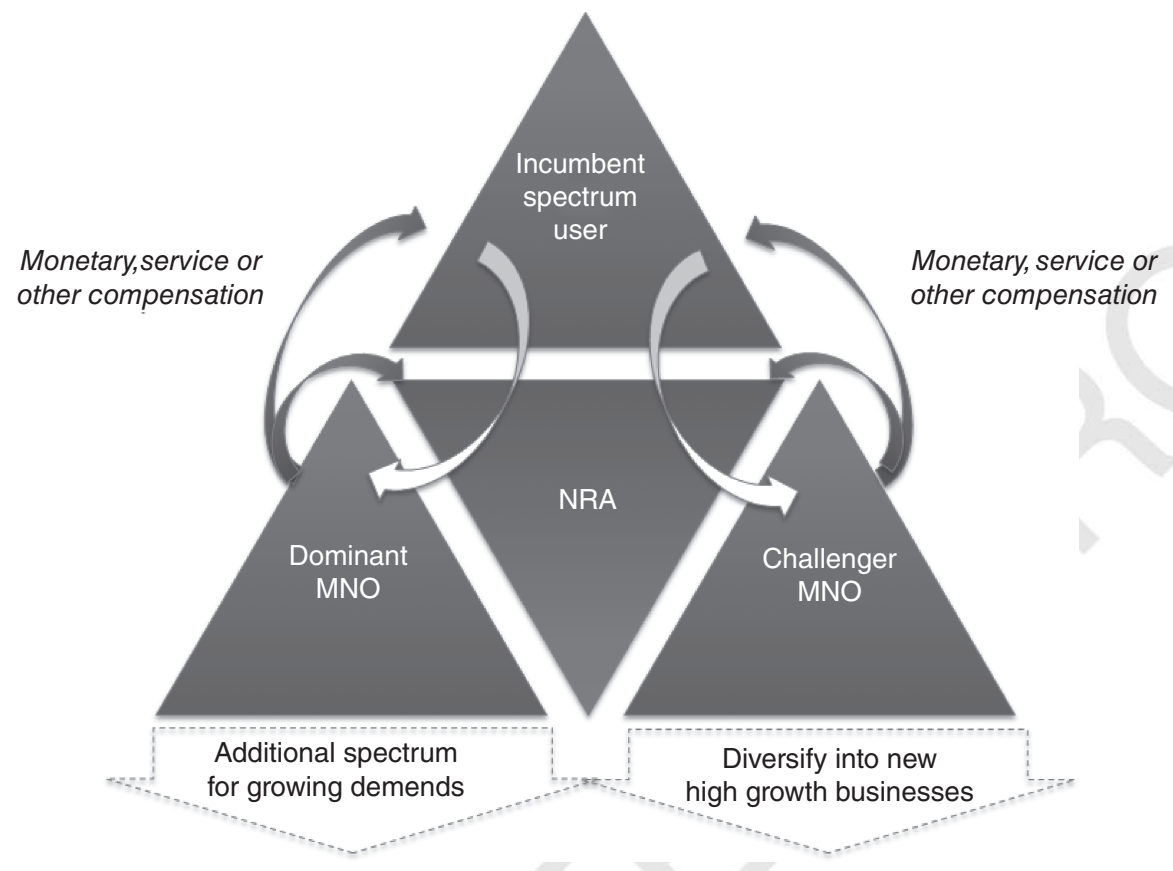

Figure 18.2 Relations between key stakeholders in the LSA concept.

For the challenger MNO, spectrum sharing can offer access to new markets or a way to improve current services and therefore the challenger can be proactive in establishing a relationship with the incumbent. Because the challenger MNO is heavily dependent on the LSA band availability, this relationship is very valuable and it could nourish the bond in order to maintain long-term companionship and also offer something valuable for the incumbent. For example, the challenger MNO could own a local fiber network without a spectrum license and gain access to LSA spectrum. It could acquire a network on the LSA band to offer local connectivity and sell it to dominant MNOs to balance their demand and supply.

For the dominant MNO, having already access to exclusive spectrum, spectrum sharing with LSA could bring additional resources to respond to the growing traffic demand by deploying a new network in the LSA band. The dominant MNO could obtain significant savings in the network expenditure by acquiring new LSA spectrum as an alternative to heavy investment to densify its existing network deployment. Another strategy for the dominant MNO, wanting to keep its dominant position in the business ecosystem, is to have a follower role and not actively promote sharing. Since the dominant MNO may not be as dependent on LSA spectrum as the challenger $\mathrm{MNO}$, the risk of LSA band unavailability is not as high for the dominating MNO and the relationship with the incumbent might not grow as strong.

Compensation for the LSA spectrum can be managed in several ways depending on the national conditions. Possible compensation flows are depicted with arrows in 
Figure 18.2. The MNO could pay monetary compensation to the NRA for the LSA license similar to traditional exclusive licenses. Thus, the LSA concept could allow the NRA to get income directly by introducing sharing in the band. This way the LSA concept could become an attractive alternative for the NRA compared to clearing the band from incumbent use and auctioning it to MNOs (i.e., spectrum refarming), which is costly and time-consuming.

In addition, the incumbent spectrum user could receive compensation from the MNOs in some format. However, depending on the national situation, the incumbent spectrum user may not have the right for this. The compensation could be an annual fee, one-time down payment or, for example, an agreed percentage of the spectrum value the incumbent spectrum user is sharing with others. In this case, the compensation between the incumbent spectrum user and the MNO is then flowing in the same direction as their business relationship: directly between the incumbent spectrum user and the MNO. The compensation can also be other than monetary, for example, services or even a business partnership to enter in other markets.

In Europe, the LSA work is currently focused on the $2.3-2.4 \mathrm{GHz}$ band [5] as the first application. In this band, the incumbent systems vary in different countries. In some countries, the incumbent is the programme making and special events (PMSE) services including video links. Due to high-definition cameras, the spectrum demand of these video links may grow leading to shortage of spectrum during major events. One potential application of the LSA concept here could be the shared use of this band between the PMSE operator and an MNO. For instance, the incumbent PMSE service provider could get the permission to use the MNO's network to deliver the incumbent's service as compensation for offering its band to be shared with the MNO.

Finally, Figure 18.3 illustrates a potential business scenario for this example incorporating other stakeholders beyond the ones previously discussed. In specific, a spectrum database provider that would potentially exist in the deployment of LSA and could be mandated by the NRA or act independently with the NRA's authorization. The MNO depends on network equipment manufacturers (NEMs) to implement new networks that encompass network solutions operating according to LSA requirements. However, a NEM would only start developing solutions incorporating LSA once there is some certainty of LSA adoption. In the same situation are device manufacturers, i.e., producers of devices and appliances for end users, which would only start adopting LSA if there is some certainty of LSA adoption by MNOs. Their goal is to improve customer experience, which in the end would also benefit MNOs and the relationship with their subscribers. Chip manufacturers are suppliers of both device manufacturers and NEMs and their goal is to sell more chips once technology is standardized and there is a market need.

\subsection{ANALYSIS OF KEY STAKEHOLDERS' NEEDS, BENEFITS, AND CONSTRAINTS}

After presenting the relationships between the key stakeholders in the LSA concept, the needs, benefits, and constraints of the stakeholders are analyzed below. This 


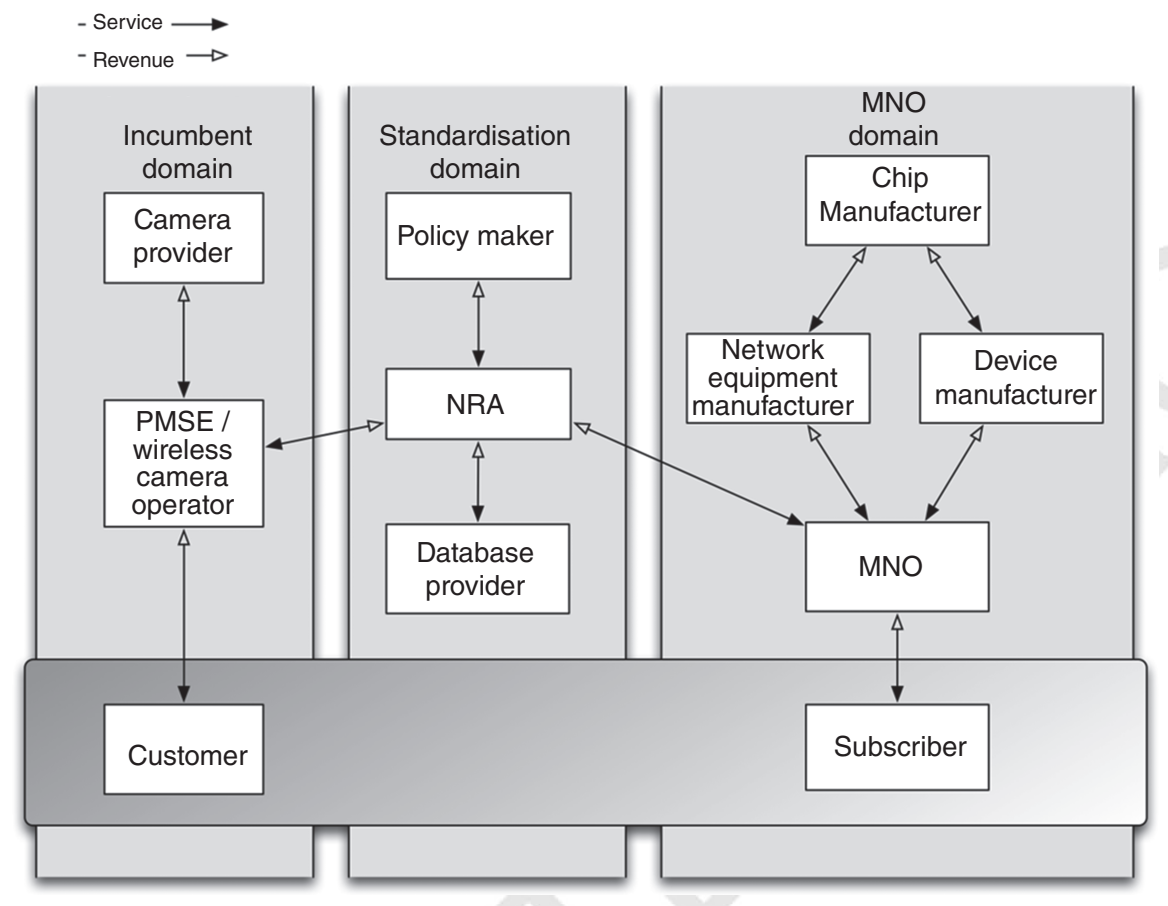

Figure 18.3 Broader view on stakeholders in LSA for the example case of 2.3-2.4 GHz band.

analysis addresses the LSA concept applied to the case of mobile broadband in a general level but is irrespective of a specific band or type of incumbent.

\subsubsection{NRA}

Table 18.1 summarizes the needs, benefits, and constraints of the NRA in the LSA concept. The NRA is responsible for issuing LSA licenses and negotiating sharing conditions/usage requirements. A key goal of the NRA is to maximize the value of the spectrum assets and balance the demand of spectrum between different wireless systems. IMT spectrum has become a means for the state to get income by auctioning new IMT bands to MNOs. Similarly, opening up new IMT bands that are currently used by other incumbents by sharing with the LSA concept could result in monetary compensations for the NRA. LSA can increase the competition in the mobile communication business by allowing several MNOs to get spectrum. The LSA is likely to create additional burden to the NRA because it requires the development of the sharing framework and specification of the rules and conditions for sharing. However, this burden could be smaller than completely clearing the band from the incumbent use and reallocating to IMT.

It is important for the NRA that the LSA concept guarantees the incumbents' rights and does not cause harmful interference to the incumbent, which is handled via the 


\section{TABLE 18.1 Needs, Benefits, and Constraints of the NRA}

\begin{tabular}{|c|c|c|c|}
\hline Need & Solution & Benefit & Constraints \\
\hline $\begin{array}{l}\text { Maximize the value } \\
\text { of spectrum assets } \\
\text { for the society. }\end{array}$ & $\begin{array}{l}\text { Assess current } \\
\text { spectrum use and } \\
\text { identify } \\
\text { opportunities for } \\
\text { LSA licensing. }\end{array}$ & $\begin{array}{l}\text { Guarantee fair access } \\
\text { to spectrum for all } \\
\text { different radio } \\
\text { communication } \\
\text { services to } \\
\text { promote } \\
\text { innovation. }\end{array}$ & $\begin{array}{l}\text { Uncertain business } \\
\text { models: scale \& } \\
\text { harmonization, } \\
\text { transaction costs } \\
\text { (cost of new } \\
\text { process), cost of } \\
\text { new technology. }\end{array}$ \\
\hline Income for the state. & $\begin{array}{l}\text { Compensation from } \\
\text { LSA licenses from } \\
\text { the MNO. }\end{array}$ & $\begin{array}{l}\text { Societal benefit from } \\
\text { natural resource. }\end{array}$ & $\begin{array}{l}\text { Ensure incumbent's } \\
\text { rights. }\end{array}$ \\
\hline $\begin{array}{l}\text { Ensure healthy } \\
\text { market } \\
\text { competition and } \\
\text { avoid monopolies. }\end{array}$ & $\begin{array}{l}\text { Offer more spectrum } \\
\text { for new and } \\
\text { existing players } \\
\text { via LSA licenses. }\end{array}$ & $\begin{array}{l}\text { Maintain reasonable } \\
\text { price level in the } \\
\text { consumer market. }\end{array}$ & $\begin{array}{l}\text { Anti-competitive } \\
\text { conduct: } \\
\text { concerns of } \\
\text { spectrum } \\
\text { concentration } \\
\text { and hoarding. }\end{array}$ \\
\hline $\begin{array}{l}\text { Increase efficiency of } \\
\text { spectrum use. }\end{array}$ & $\begin{array}{l}\text { Spectrum sharing } \\
\text { between different } \\
\text { systems/ } \\
\text { stakeholders } \\
\text { (e.g. bands used } \\
\text { for federal/ } \\
\text { governmental } \\
\text { purposes). }\end{array}$ & $\begin{array}{l}\text { Answer to the } \\
\text { growing spectrum } \\
\text { need from MNOs. }\end{array}$ & $\begin{array}{l}\text { Institutional inertial } \\
\text { and need to } \\
\text { develop new } \\
\text { sharing } \\
\text { framework. }\end{array}$ \\
\hline $\begin{array}{l}\text { Efficient and } \\
\text { effective } \\
\text { management of } \\
\text { spectrum. }\end{array}$ & $\begin{array}{l}\text { Create LSA } \\
\text { framework that } \\
\text { takes into account } \\
\text { key stakeholders' } \\
\text { requirements. }\end{array}$ & $\begin{array}{l}\text { Efficient licensing } \\
\text { process and } \\
\text { equitable } \\
\text { treatment for key } \\
\text { stakeholders. }\end{array}$ & $\begin{array}{l}\text { Additional burden } \\
\text { from the sharing } \\
\text { framework. }\end{array}$ \\
\hline $\begin{array}{l}\text { Support the } \\
\text { achievement of } \\
\text { societal targets } \\
\text { (e.g. economy } \\
\text { growth; safety). }\end{array}$ & $\begin{array}{l}\text { Use communication } \\
\text { technology as a } \\
\text { catalyst for } \\
\text { innovation } \\
\text { (e.g. national } \\
\text { broadband plans). }\end{array}$ & $\begin{array}{l}\text { Regulator fulfils its } \\
\text { societal role by } \\
\text { ensuring } \\
\text { availability of } \\
\text { spectrum for } \\
\text { different purposes. }\end{array}$ & $\begin{array}{l}\text { Finding the fair } \\
\text { balance between } \\
\text { different } \\
\text { demands of } \\
\text { different } \\
\text { services. }\end{array}$ \\
\hline $\begin{array}{l}\text { Ensure full certainty } \\
\text { for incumbents in } \\
\text { the band, without } \\
\text { operational } \\
\text { restrictions from } \\
\text { sharing with } \\
\text { others. }\end{array}$ & $\begin{array}{l}\text { Rules and conditions } \\
\text { for sharing, act in } \\
\text { case of breach of } \\
\text { contract. }\end{array}$ & $\begin{array}{l}\text { To fulfil original } \\
\text { commitments to } \\
\text { incumbent } \\
\text { spectrum user, } \\
\text { prerequisite for } \\
\text { spectrum sharing. }\end{array}$ & $\begin{array}{l}\text { Interference }(\mathrm{QoS}) \\
\text { and compliance } \\
\text { concerns. }\end{array}$ \\
\hline
\end{tabular}


sharing conditions and rules. In addition, the NRA is responsible for the coordination procedure between sharing partners in adjacent frequency bands and border coordination, which have to be taken into account in the sharing conditions. In sum, the LSA concept can offer the means for the NRA to guarantee incumbents' rights while making new spectrum available for those urgently needing it. The NRA has a societal role by ensuring sufficient amount of spectrum for different societal purposes (e.g., national broadband plans, public safety, critical infrastructures, and military) and sharing can help in fulfilling this need. The LSA concept allows the NRA to maintain its control over the spectrum as the LSA sharing framework is always defined by the NRA. Finally, the NRA aims to improve the efficiency of spectrum use and could request incumbents to use their spectrum more efficiently, for example, in the bands used for federal/governmental nonprofit purposes. There, the LSA concept could be the means for the incumbent to fulfill the regulators request allowing others to share its bands.

\subsubsection{Incumbent Spectrum User}

Incumbent spectrum user's needs, benefits, and constraints are summarized in Table 18.2. From the incumbent's point of view, the LSA concept offers a possibility to maximize the value of its current spectrum resources, but it binds it to the NRA's terms of spectrum usage and makes it dependent on the NRA. Depending on the type of incumbent, i.e. profit or nonprofit entity, and the national conditions, the benefits from LSA can differ. Regarding technology, for the incumbent spectrum sharing requires the ability to find its underutilized spectrum bands or parts of the bands and exploit them for own use or share with others with LSA. By offering the spectrum to others, the incumbent could gain monetary or other compensation from the MNO, depending on the national conditions, and that lowers the risk of the spectrum price being too high for the incumbent spectrum user. Other compensation can be, for example, utilizing the MNO's infrastructure, existing business networks for entering new markets or additional services.

For the incumbent, the spectrum sharing rules and conditions are crucial since sharing should not cause harmful interference to its own service. Here, the NRA plays an important role as the supervisor and ensures that proper rules are created and followed. For the incumbent, it is important to gain good position for negotiating the rules and conditions in order to secure own business and operations. The incumbent desires to hold the control over the LSA band and may wish to claim it back, if it is within the agreed in rules and conditions. When doing this, it could be beneficial to weight the benefits between utilizing the spectrum itself and sharing it to others and gaining compensation from it. Moreover, LSA is intended for bands identified for IMT systems that could be made solely available for mobile networks by a refarming process, in which case the incumbent would lose its license. In this case, the LSA concept could benefit the incumbent, since the urgency for refarming might be waved. 
TABLE 18.2 Needs, Benefits, and Constraints of Incumbent Spectrum User

\begin{tabular}{|c|c|c|c|}
\hline Need & Solution & Benefit & Constraints \\
\hline $\begin{array}{l}\text { Maximize the value } \\
\text { of spectrum } \\
\text { assets. }\end{array}$ & $\begin{array}{l}\text { Find underutilized } \\
\text { spectrum bands } \\
\text { (or parts of the } \\
\text { bands) and } \\
\text { exploit them by } \\
\text { sharing to others. }\end{array}$ & $\begin{array}{l}\text { Increase turnover and } \\
\text { profit. }\end{array}$ & $\begin{array}{l}\text { R\&D costs for } \\
\text { developing new } \\
\text { technology and } \\
\text { sharing conditions. } \\
\text { Dependency on } \\
\text { regulator. Building } \\
\text { new relations while } \\
\text { sharing to others. }\end{array}$ \\
\hline $\begin{array}{l}\text { Ensure service } \\
\text { continuity in the } \\
\text { future and } \\
\text { possibility to } \\
\text { expand. }\end{array}$ & $\begin{array}{l}\text { Allow sharing of } \\
\text { the bands to } \\
\text { others. }\end{array}$ & $\begin{array}{l}\text { Better position in } \\
\text { spectrum } \\
\text { refarming } \\
\text { negotiations. } \\
\text { Postpone the need } \\
\text { for refarming. }\end{array}$ & $\begin{array}{l}\text { Risk to lose part of the } \\
\text { spectrum for IMT in } \\
\text { spectrum refarming. }\end{array}$ \\
\hline $\begin{array}{l}\text { Ensure full } \\
\text { certainty of own } \\
\text { operations, } \\
\text { without } \\
\text { operational } \\
\text { restrictions from } \\
\text { sharing to others. }\end{array}$ & $\begin{array}{l}\text { Agreed rules and } \\
\text { conditions for } \\
\text { sharing between } \\
\text { incumbent, } \\
\text { MNO and } \\
\text { regulator. }\end{array}$ & $\begin{array}{l}\text { Quality of service } \\
\text { and customer } \\
\text { satisfaction are } \\
\text { maintained. }\end{array}$ & $\begin{array}{l}\text { Risk that the rules and } \\
\text { conditions are not } \\
\text { followed and own } \\
\text { business endures } \\
\text { damage. }\end{array}$ \\
\hline $\begin{array}{l}\text { Retain control over } \\
\text { the spectrum } \\
\text { band. }\end{array}$ & $\begin{array}{l}\text { Agreed rules and } \\
\text { conditions for } \\
\text { sharing, } \\
\text { possibility to } \\
\text { claim the band } \\
\text { back. }\end{array}$ & Secure own business. & $\begin{array}{l}\text { Risk that rules and } \\
\text { conditions are more } \\
\text { favourable to the } \\
\text { licensee than to the } \\
\text { incumbent. }\end{array}$ \\
\hline $\begin{array}{l}\text { Improve efficiency } \\
\text { of spectrum use. }\end{array}$ & $\begin{array}{l}\text { Share spectrum } \\
\text { bands or parts of } \\
\text { the bands to } \\
\text { others. }\end{array}$ & $\begin{array}{l}\text { Respond to } \\
\text { regulators request } \\
\text { to improve } \\
\text { efficiency of } \\
\text { spectrum use in } \\
\text { e.g. federal/ } \\
\text { governmental } \\
\text { bands. }\end{array}$ & $\begin{array}{l}\text { Risk that spectrum } \\
\text { availability for own } \\
\text { use becomes } \\
\text { restricted. }\end{array}$ \\
\hline
\end{tabular}

\subsubsection{Dominating MNO}

For the dominating MNO, the needs, benefits, and constraints in LSA are summarized in Table 18.3. The need for LSA lies in the utilization of their wide, existing customer base with growing traffic demand resulting in growing spectrum demand. The dominant MNO could gain access to new low-cost LSA bands for new 4G/5G networks without strict coverage obligations. It could obtain significant savings in the 
TABLE 18.3 Needs, Benefits, and Constraints of Dominating MNO

\begin{tabular}{|c|c|c|c|}
\hline Needs & Solution & Benefit & Constraints \\
\hline $\begin{array}{l}\text { Additional } \\
\text { spectrum to } \\
\text { respond to } \\
\text { growing traffic } \\
\text { demand. }\end{array}$ & $\begin{array}{l}\text { Sharing spectrum } \\
\text { from others. }\end{array}$ & $\begin{array}{l}\text { Access to additional } \\
\text { spectrum more } \\
\text { rapidly and } \\
\text { cheaper using LSA } \\
\text { to complement its } \\
\text { traditional } \\
\text { exclusive licenses. }\end{array}$ & $\begin{array}{l}\text { R\&D costs for } \\
\text { developing new } \\
\text { technology and } \\
\text { methods. } \\
\text { Regulatory } \\
\text { uncertainty and } \\
\text { fragmented } \\
\text { standardization. }\end{array}$ \\
\hline $\begin{array}{l}\text { Strengthen own } \\
\text { dominant } \\
\text { position in the } \\
\text { new market } \\
\text { situation. }\end{array}$ & $\begin{array}{l}\text { Cooperation with } \\
\text { incumbent } \\
\text { spectrum user and } \\
\text { prevent } \\
\text { competitors from } \\
\text { getting access to } \\
\text { new spectrum. }\end{array}$ & $\begin{array}{l}\text { Competitive } \\
\text { advantage. }\end{array}$ & $\begin{array}{l}\text { Increased } \\
\text { competition. }\end{array}$ \\
\hline $\begin{array}{l}\text { Respond to } \\
\text { growing traffic } \\
\text { demand rapidly } \\
\text { by accessing new } \\
\text { low-cost LSA } \\
\text { spectrum. }\end{array}$ & $\begin{array}{l}\text { Acquire LSA } \\
\text { spectrum instead } \\
\text { of densifying } \\
\text { existing site } \\
\text { density on } \\
\text { exclusively } \\
\text { licensed band. }\end{array}$ & $\begin{array}{l}\text { Savings in network } \\
\text { expenditure by } \\
\text { using existing sites } \\
\text { for new LSA band } \\
\text { deployment. Cost } \\
\text { of spectrum lower } \\
\text { since it includes } \\
\text { constraints. }\end{array}$ & $\begin{array}{l}\text { Risk of long-term } \\
\text { availability of } \\
\text { LSA spectrum to } \\
\text { justify LSA base } \\
\text { station } \\
\text { investments. }\end{array}$ \\
\hline $\begin{array}{l}\text { Comply with } \\
\text { regulatory } \\
\text { requirements to } \\
\text { protect } \\
\text { incumbent } \\
\text { spectrum users' } \\
\text { rights. }\end{array}$ & $\begin{array}{l}\text { Agreed rules and } \\
\text { conditions for } \\
\text { sharing between } \\
\text { incumbent, MNO } \\
\text { and regulator. }\end{array}$ & $\begin{array}{l}\text { Maintain sharing } \\
\text { rights and good } \\
\text { relations with } \\
\text { incumbent } \\
\text { spectrum user and } \\
\text { regulator. }\end{array}$ & $\begin{array}{l}\text { Negotiating/agreeing } \\
\text { rules and } \\
\text { conditions for } \\
\text { sharing, } \\
\text { dependency on } \\
\text { incumbent } \\
\text { spectrum user. }\end{array}$ \\
\hline $\begin{array}{l}\text { Balance capacity } \\
\text { demand and } \\
\text { supply in } \\
\text { network } \\
\text { congestion while } \\
\text { maintaining } \\
\text { good QoS. }\end{array}$ & $\begin{array}{l}\text { Utilize LSA bands } \\
\text { when and where } \\
\text { needed in high } \\
\text { market demand } \\
\text { areas. Offload } \\
\text { users to LSA } \\
\text { bands with } \\
\text { guaranteed QoS } \\
\text { instead of } \\
\text { offloading to WiFi. }\end{array}$ & $\begin{array}{l}\text { Avoid the need for } \\
\text { expensive reserve } \\
\text { capacity, timely } \\
\text { faster access at } \\
\text { lower cost and } \\
\text { without coverage } \\
\text { obligations. } \\
\text { Customer } \\
\text { satisfaction is } \\
\text { maintained with } \\
\text { low cost. }\end{array}$ & $\begin{array}{l}\text { Investments in new } \\
\text { base stations for } \\
\text { the LSA band, } \\
\text { concerns of } \\
\text { losing sensitive } \\
\text { network data. }\end{array}$ \\
\hline $\begin{array}{l}\text { Maximise profit } \\
\text { from } \\
\text { infrastructure } \\
\text { and new } \\
\text { spectrum assets. }\end{array}$ & $\begin{array}{l}\text { New additional } \\
\text { spectrum to offer } \\
\text { mobile wholesale } \\
\text { services to } \\
\text { MVNOs. }\end{array}$ & More profit. & $\begin{array}{l}\text { Competition } \\
\text { regulation. }\end{array}$ \\
\hline
\end{tabular}


network expenditure by acquiring new LSA spectrum and deploying base stations in existing sites, instead of densifying an existing network deployment in the exclusive spectrum band that would require heavy investment. The MNO could use the LSA band in situations of network congestion by off-loading users to the LSA band with QoS guarantees, as a complementary approach to off-loading to WiFi without predictable QoS. The timely availability of LSA bands can even be seen as a short-term solution to increasing spectrum demand before refarming.

Even though LSA represents many benefits for the dominant MNO, the threshold for accepting LSA could be higher than for the challenger MNO, since it already has access to spectrum. At the same time, the dependency on LSA band is lower for the dominating MNO reducing the risks. For dominating MNOs, LSA can offer a faster and lower cost access to new spectrum than traditional exclusive licensing, but it also represents threats from the challenger MNOs because of the lowered market entry barrier. The threats are not necessary from small domestic MNOs but from other international players who try to access new MNO business by sharing spectrum from others. Therefore, sharing spectrum from others can be a way to strengthen its dominant position in its current market by trying to gain access to all shared spectrum. The dominant MNO could then offer its extra capacity for mobile virtual network operators (MVNOs) to get income.

By utilizing LSA bands, the dominant MNO can balance the capacity need demand and supply more efficiently when required in high-demand markets and it does not need to resort to building extensive reserve capacity to serve peak demand. LSA also offers a cost-effective way to serve customers in special areas, such as rural areas, with low-cost connectivity with smaller additional investments. The challenge is to have the technology ready at the same time as the market demand for utilizing the LSA band when necessary. For the dominant MNO, there is the concern of losing sensitive data to external entities.

\subsubsection{Challenger MNO}

The needs, benefits, and constraints of LSA for challenger MNO are analyzed next, see Table 18.4. For the challenger MNO, getting access to new low-cost LSA spectrum bands is particularly appealing as it often suffers from lack of sufficient amount of spectrum. The challenger MNO could gain access to new localized business opportunities challenging the dominating MNO. Today, the access to spectrum requires acquiring licenses through auctions, which are problematic for the challenger MNOs as prices go beyond their reach. In addition, the challenger MNO could access markets that the dominating MNO is not necessarily keen to defend by reacting to direct competition.

The challenger MNO needs to be proactive in initiating the cooperation with the incumbent spectrum user and maintaining good relations to gain a good market position among other challenger MNOs. However, this depends on how the LSA licenses are awarded. The possible compensation from the challenger MNO to the incumbent is not necessarily monetary, but could also be services or resources. For challenger $\mathrm{MNO}$, it is critical to invest in globally available IMT technology. Challenger MNOs 
TABLE 18.4 Needs, Benefits, and Constraints of Challenger MNO

\begin{tabular}{|c|c|c|c|}
\hline Need & Solution & Benefit & Constraints \\
\hline $\begin{array}{l}\text { Diversify into new } \\
\text { high growth } \\
\text { businesses. }\end{array}$ & $\begin{array}{l}\text { Offer new services } \\
\text { to new customers } \\
\text { by gaining access } \\
\text { to new spectrum } \\
\text { by sharing from } \\
\text { others. }\end{array}$ & $\begin{array}{l}\text { More turnover and } \\
\text { profit with } \\
\text { minimum } \\
\text { additional } \\
\text { investments. }\end{array}$ & $\begin{array}{l}\text { R\&D costs for } \\
\text { developing new } \\
\text { technology and } \\
\text { methods, } \\
\text { dependency on } \\
\text { partners. }\end{array}$ \\
\hline $\begin{array}{l}\text { Get access to } \\
\text { new/additional } \\
\text { spectrum. }\end{array}$ & $\begin{array}{l}\text { Acquire LSA } \\
\text { licenses instead } \\
\text { of costly } \\
\text { exclusive } \\
\text { licenses from } \\
\text { auctions. }\end{array}$ & $\begin{array}{l}\text { Access to low cost } \\
\text { spectrum without } \\
\text { coverage } \\
\text { obligations. }\end{array}$ & $\begin{array}{l}\text { Risk of long-term } \\
\text { availability of LSA } \\
\text { spectrum. No } \\
\text { guaranteed service } \\
\text { continuity in case of } \\
\text { license termination. }\end{array}$ \\
\hline $\begin{array}{l}\text { Access new } \\
\text { business areas } \\
\text { (e.g. rural areas } \\
\text { and indoor } \\
\text { hotspots). }\end{array}$ & $\begin{array}{l}\text { Acquire access to } \\
\text { shared LSA } \\
\text { bands to serve } \\
\text { special market } \\
\text { demands. }\end{array}$ & $\begin{array}{l}\text { Gain market position } \\
\text { in new business to } \\
\text { enable challenging } \\
\text { dominant MNOs. } \\
\text { Invest only based } \\
\text { on local and } \\
\text { temporal needs } \\
\text { without coverage } \\
\text { obligations. }\end{array}$ & $\begin{array}{l}\text { Additional } \\
\text { infrastructure may } \\
\text { be required, } \\
\text { lowered market } \\
\text { entry threshold } \\
\text { brings new } \\
\text { competition. New } \\
\text { business costs, } \\
\text { marketing, market } \\
\text { research. }\end{array}$ \\
\hline $\begin{array}{l}\text { Affordable } \\
\text { investments (user } \\
\text { equipment, } \\
\text { network and } \\
\text { spectrum). }\end{array}$ & $\begin{array}{l}\text { Globally ready IMT } \\
\text { technology (both } \\
\text { user and network } \\
\text { equipment) for } \\
\text { the shared } \\
\text { spectrum band } \\
\text { (e.g. LTE on } 2.3 \\
-2.4 \mathrm{GHz} \text { band). }\end{array}$ & $\begin{array}{l}\text { Possibility to enter } \\
\text { the market, lower } \\
\text { entry barrier. }\end{array}$ & $\begin{array}{l}\text { Risk of long-term } \\
\text { availability of LSA } \\
\text { band. }\end{array}$ \\
\hline $\begin{array}{l}\text { Utilize regulatory } \\
\text { requirements to } \\
\text { enter new } \\
\text { business while } \\
\text { protecting } \\
\text { incumbent's } \\
\text { rights. }\end{array}$ & $\begin{array}{l}\text { Agreed rules and } \\
\text { conditions for } \\
\text { sharing between } \\
\text { incumbent, } \\
\text { MNO and } \\
\text { regulator. }\end{array}$ & $\begin{array}{l}\text { Maintain LSA rights } \\
\text { to stay in business } \\
\text { and develop close } \\
\text { relations to } \\
\text { incumbent } \\
\text { spectrum users and } \\
\text { regulator. }\end{array}$ & $\begin{array}{l}\text { Risk of service } \\
\text { discontinuity if } \\
\text { LSA band } \\
\text { availability ends. }\end{array}$ \\
\hline
\end{tabular}

must pay attention to customer value and quality of experience, and they could try to enhance customer turnover especially in areas where they access dominant MNOs' markets. Also the challenger MNO cannot cause harmful interference to the incumbent and, therefore, the reliability of the system is a crucial factor for the challenger's business, both from the business partner and customer satisfaction perspective. 


\subsubsection{Other Stakeholders}

As outlined in Figure 18.3, the LSA concept also involves other stakeholders in addition to the NRA, incumbent, and MNO. Table 18.5 summarizes the needs, benefits, and constraints for the NEM, device manufacturer, chip manufacturer, standardization organization, spectrum database provider, and end user.

As summarized in Table 18.5, NEMs have foreseen the need to sell more network solutions to make more turnover and profit. Their solution is to offer network solutions supporting the LSA concept. Their constraint with LSA is the need for $R \& D$ costs for the development of the new components, uncertainty of the concept adoption, and resulting time to market. For device manufacturer, LSA could improve customer experience by allowing users to enjoy better Quality of Excellence (QoE). Their solution is the devices supporting the LSA bands with the constraints of using standardized technology. For chip manufacturer, the LSA concept could offer the opportunity to sell more chips with lower price per chip resulting in more turnover and profit. For standardization, organizations harmonized solutions are the goal to promote economies of scale and competition. International cooperation is needed to converge. For spectrum database provider, the LSA concept offers opportunity to create new business with spectrum data by offering standardized database solutions for spectrum data. Constraints are related to security issues and information sharing. Finally, mobile broadband end users could enjoy better service experience by getting access to extra capacity with LSA. They would need to buy a new device supporting the LSA band.

\subsection{TOWARD A COMBINED VIEW}

Our analysis indicates that LSA as a new spectrum sharing solution offers new opportunities for all involved stakeholders. Especially for MNOs, it can offer the means to access new complementary spectrum bands to meet the growing traffic demand by broadening the spectrum options beyond traditional exclusive licensing and off-loading to license-exempt bands. Moreover, for the NRA, the LSA concept can become an important tool to balance the demand of the scarce spectrum resource between different types of wireless systems with distinct spectrum usage characteristics. In addition, the advantages brought by the concept to the stakeholders appear realistic as it also secures the positions of the incumbents. Thus looking at the overall picture, the LSA concept has the potential to fulfill the needs of all key stakeholders and offers them substantial benefits to be captured.

As the LSA concept is a tight interplay between the stakeholders, more research is needed to study the detailed interactions between the stakeholders in order to identify items that promote or hinder the progress of the LSA concept.

\subsection{CONCLUSIONS}

Future cellular networks can take advantage of different types of spectrum bands, namely, exclusively licensed bands, license-exempt bands, and shared bands. In the 


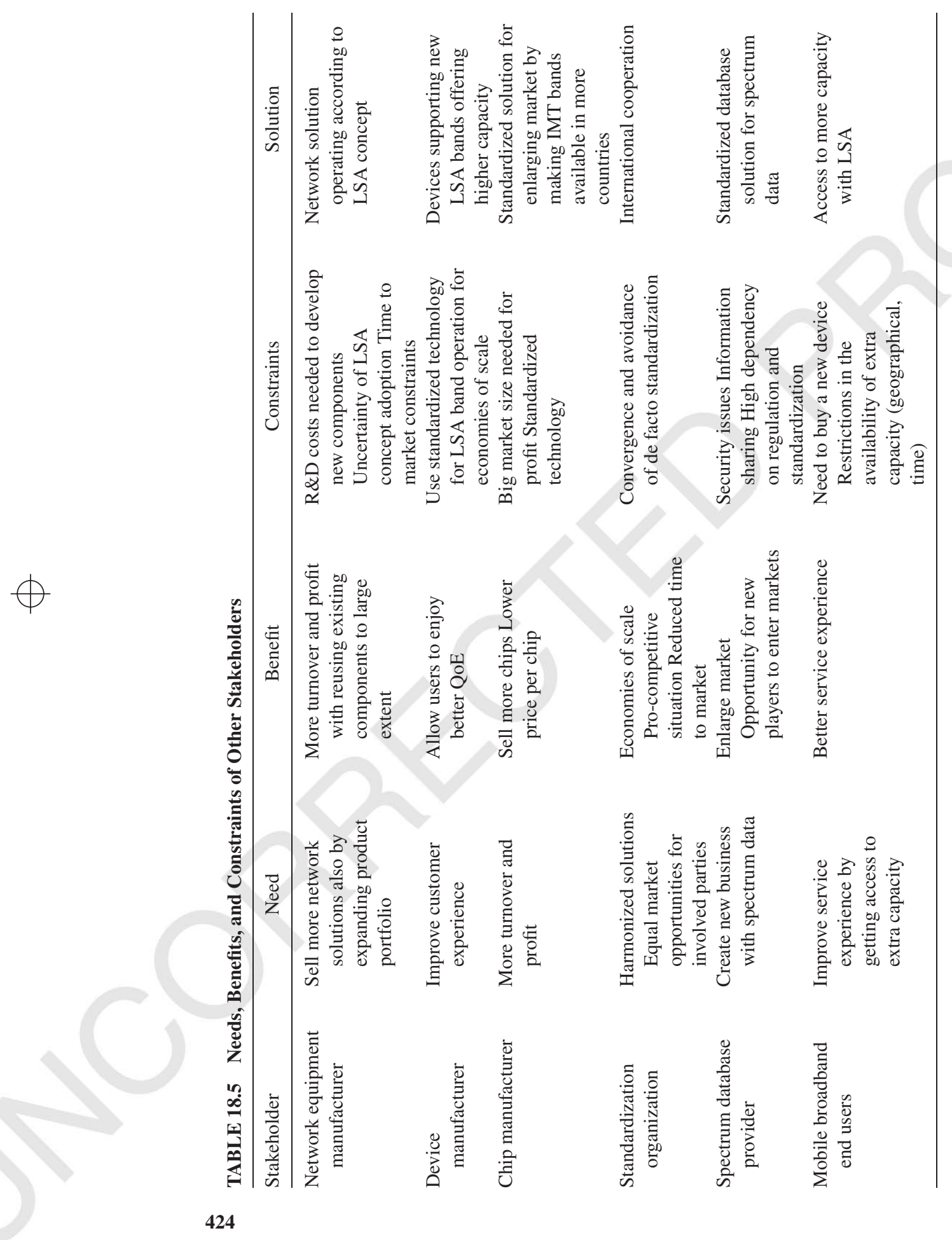


future, the role of shared bands is likely to increase as the new means to respond to the growing traffic demand in a timely fashion. The new LSA regulatory concept offers the potential for MNOs to gain access to new spectrum bands under conditions that resemble exclusive licensing while guaranteeing the incumbent spectrum users' rights. The LSA concept can speed up the process of taking harmonized IMT bands into actual use for MNOs by sharing with existing non-MNO incumbent users. Without LSA, only a minority of countries in Europe would be able to offer access to the 2.3-2.4 GHz band. In particular, an ECC harmonization measure could not be implemented without LSA. The resulting market would not be sufficiently big for major operators to deploy the band and for vendors to manufacture European handsets supporting the band.

This chapter has identified the key stakeholders in the LSA concept and considered in detail the needs, benefits, and constraints related to LSA particularly for incumbent spectrum users, MNOs (both dominating and challenger MNO), and the NRA. The LSA concept was shown to offer important benefits for all key stakeholders. Moreover, the LSA concept can be realized with utilizing existing LTE radio networks reasonable modifications to the network management infrastructure and regulatory framework. The concept has already been demonstrated in live trials and its inclusion into the regulatory and standardization framework is already underway in Europe.

Future research directions include an analysis of the roles and interactions of the different stakeholders around the LSA concept toward the practical implementation of the concept.

\section{REFERENCES}

1. Cisco Visual Networking Index: global mobile data traffic forecast update, 2013-2018. White Paper, 5th of February 2014. [Online]. http://www.cisco.com/c/en/us/solutions/ collateral/service-provider/visual-networking-index-vni/white_paper_c11-520862.pdf

2. Holma H, Toskala A. LTE-Advanced: 3GPP Solution for IMT-Advanced. John Wiley \& Sons; 2012.

3. Baldemair R, Dahlman E, Fodor E, Mildh G, Parkvall S, Selen Y, Tullberg H, Balachandran K. Evolving wireless communications: Addressing the challenges and expectations of the future. IEEE Veh Technol Mag 2013;8(1):24-30.

4. RSPG. RSPG opinion on Licensed Shared Access, European Commission, Radio Spectrum Policy Group, RSPG13-538, November 2013.

5. ETSI. Mobile broadband services in the $2300 \mathrm{MHz}-2400 \mathrm{MHz}$ frequency band under Licensed Shared Access regime, European Telecommunications Standards Institute, TR 103 113, v 1.1.1, 2013.

6. ECC. Licensed Shared Access regulatory framework, European Communications Committee, ECC Report 205.

7. Matinmikko M, Palola M, Saarnisaari H, Heikkilä M, Prokkola J, Kippola T, Hänninen T, Jokinen M, Yrjölä S. Cognitive radio trial environment: First live authorized shared access-based spectrum-sharing demonstration. IEEE Veh Technol Mag 2013;8(3):30-37. 
8. Ahokangas P, Matinmikko M, Yrjölä S, Okkonen H, Casey T. "Simple rules" for mobile network operators' strategic choices in future spectrum sharing networks. IEEE Wirel Commun 2013;20(2):20-26.

9. Lavender T, Marks P, Wongsaroj S, The economic benefits of LSA in $2.3 \mathrm{GHz}$ in Europe. Plum Consulting, December 2013, p. 51.

10. Ahokangas P, Myllykoski J, Creating and transforming business models as a practice, In Proceedings the 22nd Nordic Academy of Management Conference; 2013 August 21-23; Reykjavik, Iceland.

11. Onetti A, Zucchella A, Jones M, McDougall-Covin P. Internationalization, innovation and entrepreneurship: business models for new technology-based firms. J Manag Gov 2012;16(3):337-368.

12. March J. Exploration and exploitation in organizational learning. Organ Sci 1991; 2(1):71-87.

13. Teece D. Business models, business strategy and innovation. Long Range Plann 2010;43(2-3):172-194.

14. Hearn G, Pace D. Value-creating ecologies: understanding next generation business systems. Foresight 2006;8(1):55-65. 


\section{Queries in Chapter 18}

Q1. Please provide country name for the affiliation 4 (Vânia Gonçalves).

Q2. The sentence starting "In specific..." is incomplete. Please check. 